\title{
Surface fluxes and water balance of spatially varying vegetation within a small mountainous headwater catchment
}

\author{
G. N. Flerchinger ${ }^{1}$, D. Marks ${ }^{1}$, M. L. Reba ${ }^{1}$, Q. Yu ${ }^{2}$, and M. S. Seyfried ${ }^{3}$ \\ ${ }^{1}$ USDA Agricultural Research Service, Northwest Watershed Research Center, Boise, Idaho, USA \\ ${ }^{2}$ Plant Functional Biology and Climate Change Cluster, Department of Environmental Sciences, University of Technology, \\ Sydney, Australia \\ ${ }^{3}$ USDA Agricultural Research Service, Northwest Watershed Research Center, Boise, Idaho, USA
}

Received: 22 December 2009 - Published in Hydrol. Earth Syst. Sci. Discuss.: 22 January 2010

Revised: 28 May 2010 - Accepted: 3 June 2010 - Published: 17 June 2010

\begin{abstract}
Precipitation variability and complex topography often create a mosaic of vegetation communities in mountainous headwater catchments, creating a challenge for measuring and interpreting energy and mass fluxes. Understanding the role of these communities in modulating energy, water and carbon fluxes is critical to quantifying the variability in energy, carbon, and water balances across landscapes. The focus of this paper was: (1) to demonstrate the utility of eddy covariance (EC) systems in estimating the evapotranspiration component of the water balance of complex headwater mountain catchments; and (2) to compare and contrast the seasonal surface energy and carbon fluxes across a headwater catchment characterized by large variability in precipitation and vegetation cover. Eddy covariance systems were used to measure surface fluxes over sagebrush (Artemesia arbuscula and Artemesia tridentada vaseyana), aspen (Populus tremuloides) and the understory of grasses and forbs beneath the aspen canopy. Peak leaf area index of the sagebrush, aspen, and aspen understory was $0.77,1.35$, and 1.20 , respectively. The sagebrush and aspen canopies were subject to similar meteorological forces, while the understory of the aspen was sheltered from the wind. Missing periods of measured data were common and made it necessary to extrapolate measured fluxes to the missing periods using a combination of measured and simulated data. Estimated cumulative evapotranspiratation from the sagebrush, aspen trees, and aspen understory were $384 \mathrm{~mm}, 314 \mathrm{~mm}$ and $185 \mathrm{~mm}$. A water balance of the catchment indicated that of the $699 \mathrm{~mm}$ of areal average precipitation, $421 \mathrm{~mm}$ was lost to evapotranspiration, and $254 \mathrm{~mm}$ of streamflow was measured from the catchment;
\end{abstract}

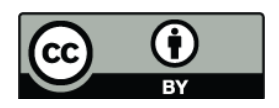

Correspondence to: G. N. Flerchinger (gerald.flerchinger@ars.usda.gov) water balance closure for the catchment was within $22 \mathrm{~mm}$. Fluxes of latent heat and carbon for all sites were minimal through the winter. Growing season fluxes of latent heat and carbon were consistently higher above the aspen canopy than from the other sites. While growing season carbon fluxes were very similar for the sagebrush and aspen understory, latent heat fluxes for the sagebrush were consistently higher, likely because it is more exposed to the wind. Sensible heat flux from the aspen tended to be slightly less than the sagebrush site during the growing season when the leaves were actively transpiring, but exceeded that from the sagebrush in May, September and October when the net radiation was not offset by evaporative cooling in the aspen. Results from this study demonstrate the utility of EC systems in closing the water balance of headwater mountain catchments and illustrate the influence of vegetation on the spatial variability of surface fluxes across mountainous rangeland landscapes.

\section{Introduction}

Mountainous headwater catchments often display considerable variability in soils, geology, vegetation and precipitation. This variability translates to variability in surface energy and mass fluxes across these catchments. Understanding the role of different vegetation communities in modulating energy, water and carbon fluxes is critical to quantifying the energy flux, carbon storage, and water balances of these headwater mountain catchments. Because the patchwork of vegetation communities within the catchment can represent a range of water and carbon flux capacities, it is difficult to estimate catchment-wide fluxes. If we know the spatial distribution of vegetation that make up this patchwork, then a comparison of measured surface fluxes from the

Published by Copernicus Publications on behalf of the European Geosciences Union. 
dominant vegetation communities can provide a framework for quantifying the balance and net energy and mass fluxes within these catchments.

Eddy covariance (EC) systems have gained popularity as a means to measure the surface energy, water and carbon fluxes. However, landscape variability and complex terrain often necessitate deployment of EC systems at less than ideal sites in order to quantify fluxes in headwater catchments. Complex terrain complicates EC measurements due to potential violations of stationarity and homogeneity assumptions. In the past decade, application of EC to measure fluxes of heat, water, and carbon has been extended to more complex sites. Baldocchi et al. (2000a) evaluated correction terms for measuring $\mathrm{CO}_{2}$ exchange above and below a forest canopy in complex terrain and concluded that $\mathrm{CO}_{2}$ was exiting the sides of the control volume beneath the forest canopy. Turnipseed et al. $(2002,2003)$ demonstrated that closure of the energy balance over a sub-alpine forest in complex topography was dependent on friction velocity and that the local canopy exerted a greater influence on the statistical measures of turbulence (e.g. roughness lengths, spectral peaks, turbulent length scales) than did the local topography. They observed drainage flows near the ground surface similar to those by Baldocchi et al. (2000a) which biased measurements of $\mathrm{CO}_{2}$ flux, particularly under stable, stratified conditions. Kosugi et al. (2007) used three years of EC measurements to assess the seasonal and inter-annual variations in sensible and latent heat fluxes of a cypress forest with complex topography. Hiller et al. (2008) assessed the quality of EC techniques on an alpine grassland in highly complex terrain using energy balance closure techniques and concluded that data quality was generally more consistent when wind direction was along the valley axis as opposed to when winds were transitional. Pomeroy et al. (2003) evaluated surface energy fluxes associated with snow ablation in a mountainous subarctic tundra valley.

Several studies have been conducted using EC systems that contrast and compare the influence of vegetation type on energy and carbon fluxes within different vegetation communities. Baldocchi et al. (2004), for example, contrasted the partitioning of the surface energy balance of an oak savanna and grassland in response to available soil moisture. They found that the grassland senesced and stopped transpiring earlier than the oak trees due in part to the trees being able to tap deeper water sources. By deploying EC systems above and below woodland canopies, Scott et al. (2003) and Paco et al. (2009) found similar results in the apparent decoupling of the moisture source for the canopy understory versus the overstory due also to the trees tapping deeper moisture.

Despite the limitations of EC systems beneath a forest canopy, several studies have found the method capable of accurately quantifying fluxes of the forest understory (Baldocchi et al., 2000b; Marks et al., 2008; Reba et al., 2009b) and have partitioned fluxes within the canopy by having separate EC systems above and below the canopy (Blanken et al., 1997; Constantin et al., 1999; Blanken et al., 2001; Wilson et al., 2000; Scott et al., 2003; Jarosz et al., 2008). Marks et al. (2008) presented an analysis of the snow cover energy and mass balance (including sublimation) showing that EC measurements below a pine canopy closely matched simulated values and the observed mass balance. Molotch et al. (2007) used measurements above and below a subalpine forest canopy to partition sublimation of snow from the snowpack and intercepted snow. Roupsard et al. (2006) was able to validate understory measurements of evaporation within a coconut plantation by differencing total evapotranspiration (ET) measured above the canopy with sap flow measurements of transpiration. Misson et al. (2007) used 10 sites within the FLUXNET network to demonstrate that while understory EC measurements are problematic at night due strong inversion layers, measurements during the daytime were generally reliable. Reba et al. (2009a,b) presented data quality parameters of measured sublimation from an aspen understory that were of high quality in comparison to published criteria.

EC applications to understory vegetation are subject to much caution because the underlying hypotheses are generally not valid in conditions typically present in forest understories, i.e. low wind speed, strong heterogeneity, and intermittent turbulence. Wilson and Meyers (2001) addressed the issue of spatial heterogeneity in a forest understory by comparing the variability of three EC systems beneath a deciduous forest canopy; while a measure of variation in measured fluxes was 0.14 for their collocated systems compared to 0.54 for systems separated by $30 \mathrm{~m}$, variability between systems decreased as the number of half-hour sampling periods used to obtain mean fluxes was increased. After $48 \mathrm{~h}$, variation decreased to 0.07 and 0.09 , respectively. Energy balance closure represents a powerful test to determine whether the eddy flux measurements are representative, which Lamaud et al. (2001) used to demonstrate the validity of EC measurements in the understory of a pine forest.

Few studies have used EC systems to quantify the variability in surface fluxes within headwater mountain catchments, nor demonstrated the use of EC systems to close the water balance in these mountainous catchments. While Scott (2010) did demonstrate the use of EC systems to close the water balance of three semi-arid catchments, each site was composed of a single vegetation communtiy and free of the complications due to snowcover and the resulting high degree of spatial variability of water input across the catchment (e.g., Marks and Winstral, 2001; Marks et al., 2002) The focus of this paper is twofold: (1) to assess the use and accuracy of EC systems in estimating the evapotranspiration (ET) component of the water balance in a complex headwater catchment; and (2) to compare and contrast the seasonal surface energy and carbon fluxes across a headwater mountain catchment characterized by large variability in precipitation and vegetation cover. The former uses a novel approach to extend the EC measurements to missing periods 


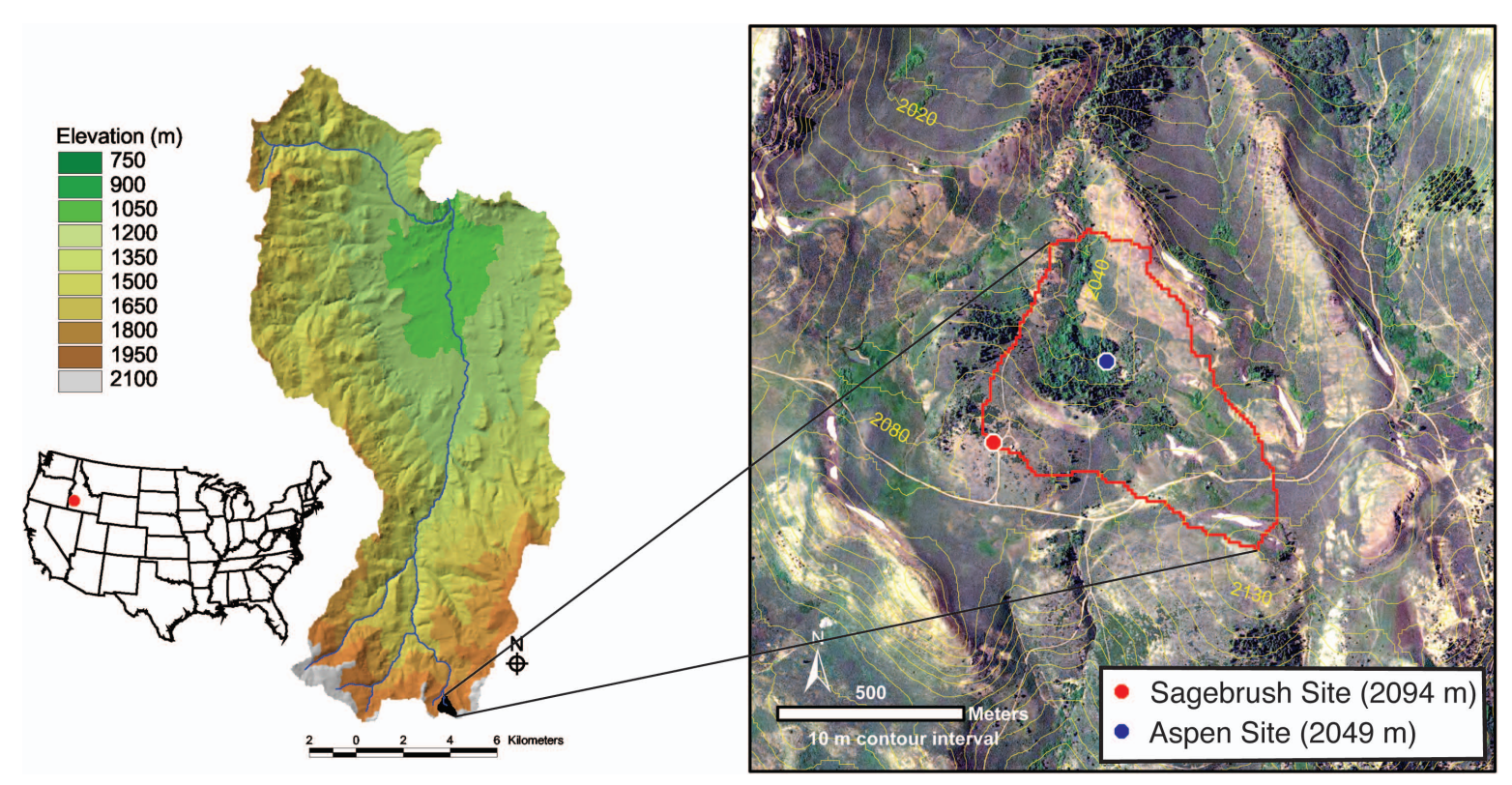

Fig. 1. Location map of Reynolds Mountain East Catchment.

in this complex environment. The latter will elucidate the roles that the different vegetation types have in modifying the timing and magnitude of the energy and carbon fluxes. To accomplish these objectives, EC systems were used to measure surface fluxes over sagebrush, aspen and the understory of grasses and forbs beneath the aspen canopy. These vegetation communities are ubiquitous throughout the forests and intermountain shrub steppe of the Western US (Barbour and Billings, 2000; Clark et al., 2001). The intermingling of these communities causes a complex mosaic of vegetation that is a common feature in these landscapes.

\section{Materials and methods}

\subsection{Site description and field measurements}

The study area is the Reynolds Mountain East (RME) catchment located in the southwestern portion of the Reynolds Creek Experimental Watershed (RCEW) operated by the USDA Agricultural Research Service, Northwest Watershed Research Center. RCEW is located in the Owyhee Mountains of Southwestern Idaho, USA. RME is a 39.0 ha headwater catchment that ranges in elevation from 2024 to $2139 \mathrm{~m}$ a.s.l. (Pierson et al., 2001) (Fig. 1). The catchment is dominated by low and mountain big sagebrush (Artemesia arbuscula and Artemesia tridentada vaseyana) and rocky ground covering 69\% of the catchment; patches of aspen (Populus tremuloides) and willow cover $26 \%$ and fir covers the remaining $5 \%$ of the catchment area.
Spatial variability in precipitation is a dominant feature of the hydrology within the Reynolds Creek Experimental Watershed and has been documented by many investigators (Johnson and Hanson, 1995; Flerchinger and Cooley, 2000; Hanson, 2001; Marks and Winstral, 2001; Marks et al., 2002; Winstral and Marks, 2002). The 40-year average annual wind-corrected precipitation is $795 \mathrm{~mm}$ at the sagebrush site and $1010 \mathrm{~mm}$ measured in a clearing in the aspen stand approximately $100 \mathrm{~m}$ from the aspen EC tower. Dual-gauge precipitation systems especially designed for the windy and snow-dominated conditions prevalent in the area were used to measure precipitation (Hanson, 1989; Hanson et al., 1999, 2004). Effective precipitation, modulated by snow drifting during the winter months, is quite variable over the watershed. The exposed ridges and sagebrush areas tend to be windswept and accumulate approximately a meter of snow during the winter. Conversely, the area immediately upslope of the aspen typically accumulates $6 \mathrm{~m}$ of snow, which sustains the aspen and fir trees in this topographically-sheltered area (Fig. 1).

Three eddy covariance sites were established to monitor fluxes across the RME catchment as part of a long-term study to characterize the hydrology of this mountainous headwater catchment. The wind-exposed sagebrush site was operated from October 2002 until January 2008. Measurements below the aspen were initiated in December 2004 and above the aspen in February 2007. Analyses of this study focus primarily on 2007 when all three systems were operational; data for above the aspen were extrapolated to complete the 2007 water year (October 2006 through September 2007). The sites are representative of the two major landscape units in the catchment. 
Vegetation at the sagebrush site consists of about half sagebrush with the remainder consisting of equal amounts of native grasses and forbs. Vegetation is approximately $60 \mathrm{~cm}$ in height with a leaf area index (LAI) of 0.77 based on point frame measurements. The site is a gently rolling ridge top with slope varying from 1 to $3 \%$. The aspen site consists of an aspen grove with an understory of grasses and forbs. An inventory of the trees in the immediate vicinity $(0.20 \mathrm{ha})$ of the EC system indicated a density of 1280 trees/ha with an average diameter of $14.6 \mathrm{~cm}$ at a height of $1.3 \mathrm{~m}$. Average height was $9.5 \mathrm{~m}$ and the maximum tree height was $15 \mathrm{~m}$. Stem area index (SAI) of the trunks and limbs based on measurements using a light interception instrument (LAI-2000, Li-Cor, Inc., Lincoln, Nebraska) prior to the growing season was 0.5. Maximum leaf area index (LAI) of the aspen measured during the growing season using an LAI-2000 was 1.35 in August. Understory vegetation measurements indicated an LAI of approximately 1.2 for the grasses and forbs, which were about $75 \mathrm{~cm}$ in height. An inventory of the fir trees located to the south of the aspen grove was also conducted; LAI of the fir trees measured using the LAI-2000 was 2.0.

EC systems used to measure turbulent fluxes consisted of a three-dimensional sonic anemometer (Model CSAT3, Campbell Scientific, Inc., Logan UT) and an open path infrared gas analyzer (IRGA; Model LI-7500, LI-COR, Inc., Lincoln, NE) sampled at $10 \mathrm{~Hz}$. The EC systems were located at $5 \mathrm{~m}$ above the ground surface at the sagebrush site, and $4.5 \mathrm{~m}$ and $19.25 \mathrm{~m}$ at the aspen site. Short and long wave radiation, air temperature and humidity were collected every 30 min using a four-component net radiometer (CNR-1, Kipp \& Zonen, Delft, The Netherlands), and a temperature and humidity probe (HMP45C, Viasala, Helsinki, Finland). Ground heat flux was measured with up to six heat flux sensors (HFP01, Hukseflux, Netherlands) installed 0.08-m deep within the soil and three sets of self-averaging thermocouples installed at 0.02 and $0.06-\mathrm{m}$ deep. A single set of soil heat flux sensors were shared by the understory and above aspen sites. Soil moisture used to compute volumetric heat capacity of the soil was measured hourly at $0.03 \mathrm{~m}$ using Hydra-probe II soil moisture sensors. The understory site also included sensors in the soil profile down to approximately $1 \mathrm{~m}$; the soil moisture profile at the sagebrush site was measured periodically to a depth of $1.2 \mathrm{~m}$ using a neutron probe.

\subsection{Processing eddy covariance and energy balance data}

The surface energy balance can be described by the surface energy balance equation: $R_{\mathrm{n}}-G-\Delta S_{\mathrm{sp}}-\Delta S_{\mathrm{c}}=-(H+\mathrm{LE})$, where $R_{\mathrm{n}}$ is net radiation, $G$ is soil heat flux at the surface, $\Delta S_{\mathrm{sp}}$ is the change in heat stored within the snowpack if present, $\Delta S_{\mathrm{c}}$ is change in heat stored within the vegetation canopy, and $H$ and LE are turbulent sensible and latent heat fluxes. All fluxes are assumed positive in the down- ward direction. Post-processing of the 30-min EC data followed the protocols described by Reba et al. (2009b). They consisted of sonic temperature correction (Schotanus et al., 1983), density correction (Webb et al., 1980), and coordinate rotation (Kaimal and Finnigan, 1994). Soil heat flux measured at $0.08 \mathrm{~m}$ was corrected for heat storage above the heat flux plates. Heat stored within the canopy was computed from the empirical equation $\Delta S_{\mathrm{c}}=C(\Delta T / \Delta t)+D$ based on Blanken et al. (1997) and used in several studies (Arain et al., 2003; Wu et al., 2007), where $\Delta T$ is the change in temperature over the observed time period $\Delta t$, and $C$ and $D$ account for heat storage characteristics of the trees, shrubs, and air column within the canopy. Values of $C$ for the sagebrush, aspen, aspen understory were $1.7,9.5$, and $2.4 \mathrm{~J} / \mathrm{C}$, respectively; $D$ was assumed negligible. For comparison, Arain et al. (2003) used values of $13.5 \mathrm{~J} / \mathrm{C}$ for $C$ and $1.66 \mathrm{~W} \mathrm{~m}^{-2}$ for $D$ in a black spruce stand with 5900 trees/ha, and Wu et al. (2007) used value of $16.2 \mathrm{~J} / \mathrm{C}$ and $1.5 \mathrm{~W} \mathrm{~m}^{-2}$ for a mixed forest having a mean canopy height of $26 \mathrm{~m}$. Quality of the EC data assessed by energy balance closure was limited to periods without snow cover because snow temperatures and energy stored within the snowpack were not available to assess $\Delta S_{\mathrm{sp}}$.

Wind direction had very little effect on energy balance closure for the aspen understory. The above aspen tower was located near the northeast edge of the aspen grove to maximize fetch. Therefore periods when the wind did not originate from the direction of the aspen $\left(170^{\circ}\right.$ to $290^{\circ}$ from north) were removed from analysis for the above aspen site. The sagebrush site, located on a gently rolling hilltop, slopes approximately $2.4 \%$ to the north and west, $1.8 \%$ to the south, and is level to the east, so energy balance closure was assessed for each of the cardinal wind directions.

Flux data were filtered for spikes, instrument malfunctions, and out-of-range signals. Out-of-range water vapor and $\mathrm{CO}_{2}$ concentration accounted for approximately $90 \%$ of the poor quality data. Data were screened for representative periods during each month of 2007 when plotted turbulent fluxes from the three sites looked reasonable. Composite hourly averages were computed for typically 10 to 20 day periods within each month. These periods were selected because they had generally complete EC and meteorological data. Even so, approximately $22 \%$ of the hourly values for these periods were rejected for the sagebrush and aspen understory, and approximately $52 \%$ for the above aspen site due to either data quality or unfavorable wind direction. Data were not available from the aspen understory site for some of the months (September, October and December) due to power supply problems.

A footprint analysis was conducted for the three sites similar to that developed by Schuepp et al. (1990) and summarized by Blanken et al. (2001). Numerous approaches exist for footprint analysis. The method described by Schuepp (1990) was chosen for its simplicity and robustness. The upwind horizontal distance exerting the maximum influence on 
flux observation is given by

$x_{\max }=\phi_{\mathrm{m}}\left(U / u^{*}\right)[(z-d) / 2 k]$

where $\phi_{\mathrm{m}}$ is the stability correction for momentum, $u^{*}$ is friction velocity, $z$ is measurement height, $d$ is the zero plane displacement, taken as 2/3 of vegetation height, $k$ is the von Karman constant and $U$ is height-averaged wind speed given as

$U=\frac{u^{*}\left[\ln \left((z-d) z_{0}-1+z_{0} /(z-d)\right)\right]}{k\left(1-z_{0} /(z-d)\right)}$.

Here, $z_{0}$ is the surface roughness, taken as 0.13 of the vegetation height. The cumulative normalized contribution to the flux over a fetch of distance $x$ is given by

$Q(x) / Q=\exp \left[\left(-\phi_{\mathrm{m}} U(z-d) /\left(k u^{*} x\right)\right)\right]$.

As pointed out by Schmid (2002), the flux footprint relationship developed by Schuepp (1990) is derived using crude assumptions, but its overall characteristics are the same as those of more sophisticated modern footprint models. We acknowledge the limitations of this approach for our situation, but this quantitative tool is nonetheless helpful to estimate the representativeness of our measurements.

\subsection{Model simulations}

EC data are rarely serially complete and invariably have gaps due to instrument malfunctions and unfavorable wind direction. Thus, model simulations from the Simultaneous Heat and Water (SHAW) model (Flerchinger et al., 1996) were used to: assess the representativeness of the measured flux data within the 10 to 20 day periods used to compare fluxes from the three sites; and extrapolate the measured periods to monthly ET estimates. The SHAW model has been tested and applied extensively over a range of vegetation types in semi-arid and arid environments, particularly in the surrounding RCEW (Flerchinger et al., 1996, 1998), and Link et al. (2004) previously validated the model for fir forest canopies. The model simulates the surface energy balance, evapotranspiration and fluxes within a multispecies plant canopy using detailed physics of heat and water transfer through the soil-plant-atmosphere continuum, making it ideal for use in this study. The model was initialized with measured soil temperature and water profiles and driven with observed air temperature, wind speed, humidity, precipitation and solar radiation at each of the sites where available. Meteorological data from the sagebrush site was used to drive the above aspen simulation for the period before the tower was installed. Solar radiation for the aspen understory was estimated from above-aspen simulations because measured incoming solar radiation was not always representative of the aspen understory due to gaps in the canopy, as discussed subsequently.

\section{Results}

\subsection{Meteorological conditions}

Average meteorological conditions for each month of 2007 are plotted for each site in Fig. 2. Total wind-corrected precipitation measured during 2007 was $704 \mathrm{~mm}$ at the sagebrush site and $759 \mathrm{~mm}$ at the aspen site, which are $89 \%$ and $75 \%$ of normal. Typical of the mountainous western US, conditions are characterized by cool wet winters and hot dry summers as indicated by the separation between air temperatures and dew point temperatures (Fig. 2c). Meteorological conditions are very similar for the sagebrush and above aspen, while the solar radiation and wind speed are moderated considerably for the aspen understory. Solar radiation measured below the aspen reaches a maximum in May prior to the aspen trees leafing out. Typical wind speeds below the aspen are $1 \mathrm{~m} \mathrm{~s}^{-1}$ while those above the aspen and sagebrush are around $4 \mathrm{~m} \mathrm{~s}^{-1}$. Average understory temperatures tend to be lower than the other sites, except for May; solar radiation penetration prior to aspen leaf-out resulted in high solar radiation values beneath the aspen for this month and likely contributed to the higher temperatures.

\subsection{Energy balance closure and footprint analysis}

EC systems are well known for their inability to close the energy balance (Twine et al., 2000; Wilson et al., 2002). Energy balance closure for the months free of snow was assessed following the lead of Wilson and Baldocchi (2000) by regressing $R_{\mathrm{n}}-G-S_{\mathrm{c}}$ on $-(H+\mathrm{LE})$ during periods when snow was not present. Figure 3 gives a plot of $R_{\mathrm{n}}-G-S_{\mathrm{c}}$ versus $-(H+\mathrm{LE})$ for monthly average values of each hour for May through October; the resulting regressions are given in Table 1. Although the slope for the sagebrush (0.84) is quite good and that for the above aspen site is acceptable (0.74), the slope of 0.38 for the aspen understory site suggests a general lack of energy closure. The lack of energy balance closure for the aspen understory site can be attributed to unrepresentative net radiation measurements. Gaps in the canopy exposed the net radiometer in the understory to direct radiation during the mid-afternoon hours (typically $1300 \mathrm{~h}$ to $1700 \mathrm{~h}$ as well as $0900 \mathrm{~h}$ ), as illustrated in Fig. 4a. Incoming solar radiation measured at the sensor was therefore not representative of the average solar radiation flux received beneath the aspen canopy, so closure cannot be expected during these hours. Upon excluding these hours from the energy balance closure analysis, the slope of the regression line improves to 0.70 . Even so, spatial measurement of radiation beneath the canopy, similar to the approach used by Baldocchi et al. (2000b), would be preferred. Thus, net radiation comparisons for the aspen understory, particularly during the afternoon hours, should be done with caution; however there is nothing to suggest that the turbulent fluxes beneath the canopy are not reliable. 
Table 1. Characteristics of energy budget closure by regressing $-(H+\mathrm{LE})$ versus $\left(R_{\mathrm{n}}-G-S\right)$.

\begin{tabular}{lccc}
\hline Site & Slope & Intercept $\left(\mathrm{W} \mathrm{m}^{-2}\right)$ & $R^{2}$ \\
& & & \\
\hline Sagebrush & 0.84 & 22.5 & 0.96 \\
Above aspen & 0.74 & 29.5 & 0.95 \\
Aspen understory & 0.38 & 19.2 & 0.76 \\
Aspen understory (excluding mid-afternoon hours) & 0.70 & 12.6 & 0.80 \\
\hline
\end{tabular}

Using EC systems in the aspen understory is subject to much caution because the underlying hypotheses are generally not valid in the prevailing understory conditions. Reba et al. (2009b), however, reported the data quality from the aspen understory site during the snow season to be of high quality in comparison to published criteria. While variability in the understory is an issue, the fluxes averaged over several days during each monthly observation period and the reasonable energy balance closure obtained after removing the unrepresentative net radiation data suggest that the EC measurements are representative of average fluxes in the aspen understory (Wilson and Meyers, 2001; Lamaud et al., 2001).

Analysis of the sagebrush energy balance closure for wind coming from each of the four cardinal directions revealed that the slope of the energy balance closure ranged from 0.78 for east winds to 0.89 for north winds compared to 0.84 for all directions. A dummy-variable regression analysis (Fox, 2008, Chapt. 7) found that the slope of the energy balance closure for north winds was significantly different from the slopes for other wind directions. It is unclear why the slope of the energy balance closure was greater for north winds as the topography faces slightly north in that direction and the net radiation measurements at the tower would presumably overestimate the available energy from where the turbulent fluxes originate. Nevertheless, data for the sagebrush site was not screened for wind direction, as energy balance closure is reasonable for all directions.

Magnitude of the canopy storage term $S_{\mathrm{c}}$ was a minor component of the energy balance, ranging from $2 \mathrm{~W} \mathrm{~m}^{-2}$ during the winter months to $7 \mathrm{~W} \mathrm{~m}^{-2}$ during the summer for the above aspen site. This accounted for approximately $10 \%$ of $R_{\mathrm{n}}$ during the winter and $3 \%$ during the summer; the magnitude of $S_{\mathrm{c}}$ typically accounted for $1 \%$ or less of $R_{\mathrm{n}}$ at the sagebrush site and 1 to $2 \%$ at the aspen understory.

Based on footprint analysis, distance from the instruments exerting the maximum influence on measured fluxes under neutral conditions was $54 \mathrm{~m}$ for the sagebrush site, $46 \mathrm{~m}$ for the aspen understory, and $36 \mathrm{~m}$ for the above aspen site. Under typical unstable daytime conditions, these distances reduced to $42 \mathrm{~m}, 36 \mathrm{~m}$, and $28 \mathrm{~m}$, respectively. Fetch is not a concern for most wind directions at the sagebrush site, however the aspen sites are limited to approximately $160 \mathrm{~m}$ of fetch for acceptable wind directions. For unstable con-

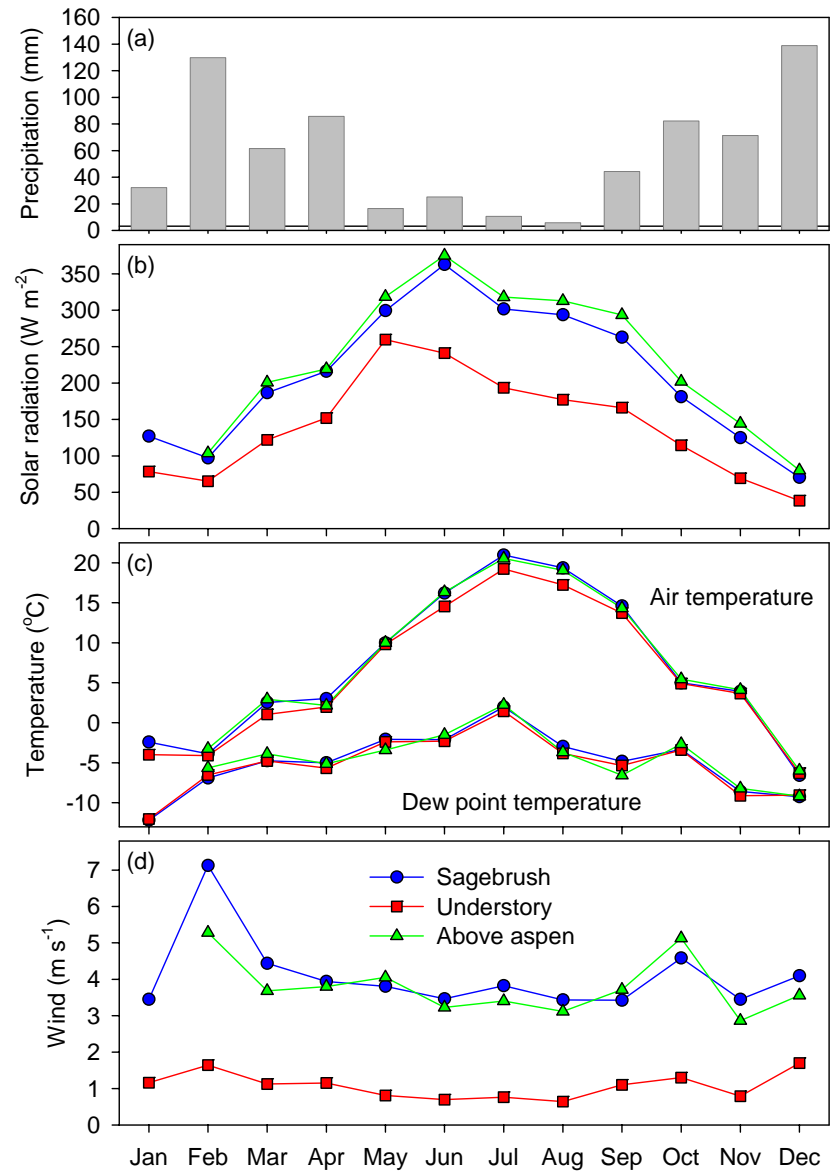

Fig. 2. Monthly meteorological averages for the three study sites within Reynolds Mountain East.

ditions, approximately $70 \%$ of the flux upwind of the towers originated within this fetch, however this dropped to approximately $60 \%$ under neutral conditions and commonly dropped below $50 \%$ for stable conditions within the understory. Although stable conditions of the aspen understory, which were common at night, may be biased by upwind vegetation, these periods were not removed from the analysis. It is expected that systematically removing these periods with strong downward sensible heat flux would bias the results more than the influence of the upwind vegetation. 
Table 2. Regression coefficients and root mean square deviation (RMSD) between simulated and measured monthly averaged fluxes for each hour.

\begin{tabular}{llcccc}
\hline Site & Flux & Slope & $\begin{array}{c}\text { Intercept } \\
\left(\mathrm{W} \mathrm{m}^{-2}\right)\end{array}$ & $R^{2}$ & $\begin{array}{c}\text { RMSD } \\
\left(\mathrm{W} \mathrm{m}^{-2}\right)\end{array}$ \\
\hline Sagebrush & Net radiation & 1.09 & 15.1 & 0.98 & 32.8 \\
& Latent heat & 1.10 & -6.9 & 0.86 & 22.0 \\
Above Aspen & Sensible heat & 1.01 & 0.9 & 0.94 & 22.5 \\
& Net radiation & 0.91 & 2.0 & 0.98 & 36.8 \\
& Latent heat & 0.94 & -14.2 & 0.88 & 28.9 \\
Aspen Understory & Sensible heat & 1.18 & 8.4 & 0.94 & 32.1 \\
& Net radiation & \\
& Latent heat & 0.93 & 2.1 & 0.83 & 36.3 \\
& Sensible heat & 0.77 & 5.2 & 0.67 & 22.6 \\
\hline
\end{tabular}

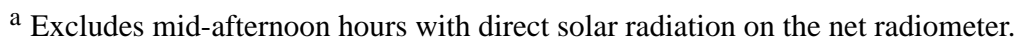

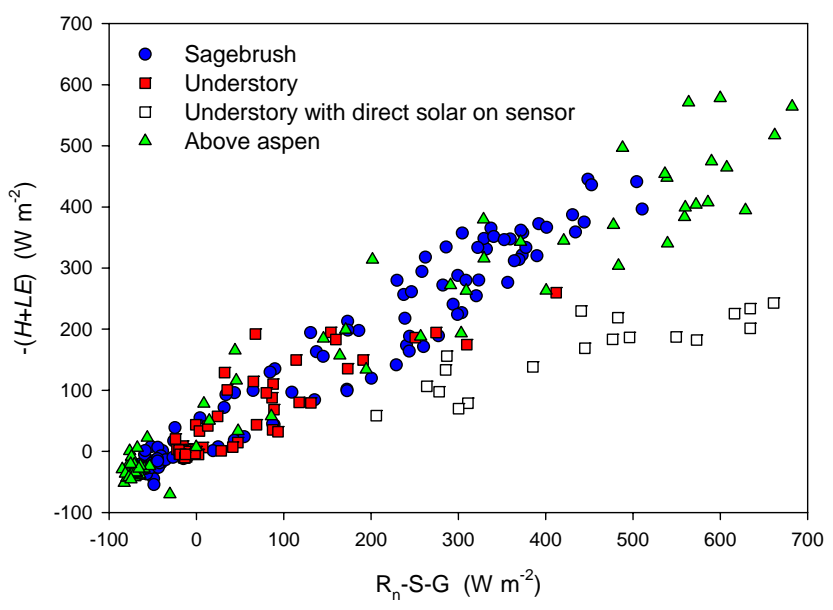

Fig. 3. Scatter plot of monthly averaged hourly values of $-(H+\mathrm{LE})$ versus $\left(R_{\mathrm{n}}-G-S\right)$.

\subsection{Representativeness and extrapolation of fluxes}

Average monthly values for each hour for the sagebrush and the aspen understory had approximately $22 \%$ missing values and values for above the aspen had about 52\% missing values due to instrument malfunction and unfavorable wind direction. Thus, the SHAW model, after assessing its ability to match observed fluxes, was used to assess the representativeness of fluxes after data filtering. Table 2 gives regression coefficients and root mean square deviations (RMSD) between simulated and measured monthly averaged fluxes for each hour. Simulations were quite good above the sagebrush and both above and below the aspen, with RMSD between simulated and measured fluxes being around $35 \mathrm{~W} \mathrm{~m}^{-2}$ for net radiation and between 22 and $32 \mathrm{~W} \mathrm{~m}^{-2}$ for the turbulent fluxes. By comparison, Flerchinger et al. (1998) reported RMSD values between 28 and $56 \mathrm{~W} \mathrm{~m}^{-2}$ for turbulent fluxes simulated by SHAW for semi-arid grasslands and

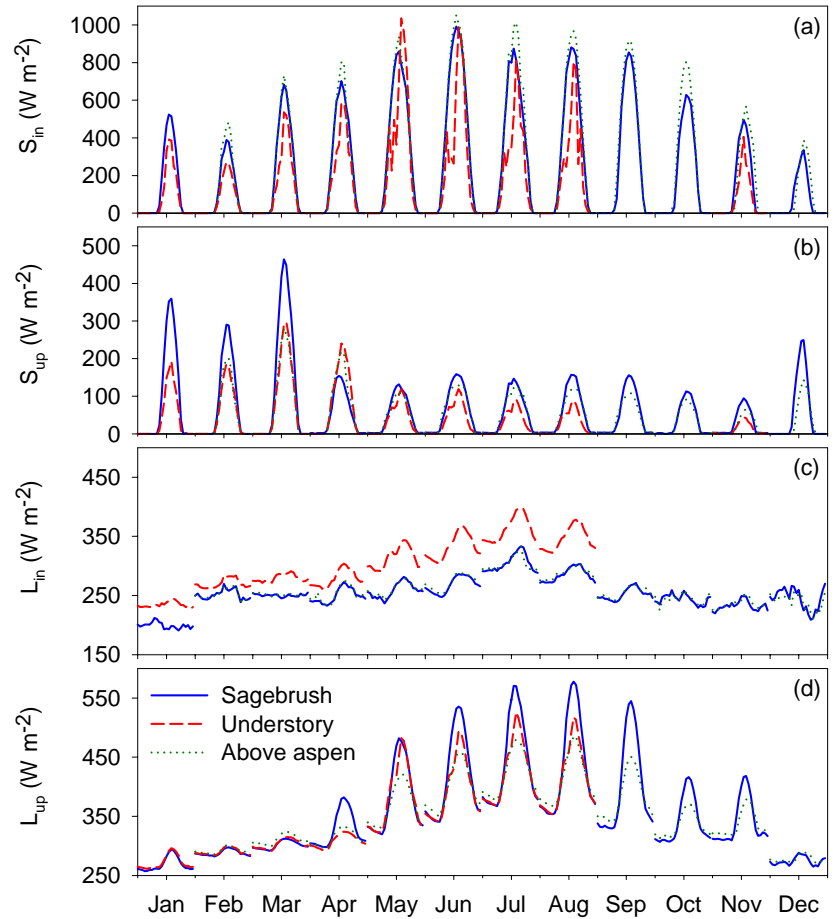

Fig. 4. Average diurnal variation in incoming $\left(S_{\text {in }}\right)$ and reflected $\left(S_{\text {up }}\right)$ solar radiation and incoming $\left(L_{\text {in }}\right)$ and emitted $\left(L_{\text {up }}\right)$ longwave radiation fluxes for the three study locations. (Data are not available for the aspen understory during September, October and December, nor for above the aspen during January.)

shrublands. Simulated net radiation for the aspen understory was quite reasonable given that it excluded mid-afternoon hours when there was direct solar radiation on the net radiometer, and relied on simulated radiation transfer within the aspen canopy from the above aspen measurement. 
The reasonably high $R^{2}$ for simulated latent heat flux for the sagebrush and above aspen (0.86 and 0.88) suggests that the trends were captured reasonably well and the ratio between simulated and measured values can be used to assess the representativeness of the observed fluxes and to extrapolate the latent fluxes for the water balance. The somewhat lower $R^{2}$ value $(0.72)$ for the aspen understory suggests that extrapolated latent heat fluxes for the understory need to be used with caution, however they are not critical to the catchment water balance.

The mean absolute differences in monthly averaged fluxes simulated by the SHAW model using only the hours with observed fluxes versus using all hours for each period was approximately $5 \mathrm{~W} \mathrm{~m}^{-2}$ at the above aspen site. By comparison, differences in simulated values with and without the missing periods were within $2 \mathrm{~W} \mathrm{~m}^{-2}$ at the sagebrush and aspen understory sites. While the difference for other fluxes and other sites varied from positive to negative, simulated average latent heat flux using only the hours with observed fluxes above the aspen was consistently lower than that using all the hours in the period. Thus, there may be less evaporative demand when winds are from the north and east, which were removed from the analysis due to unfavorable wind direction, and latent heat flux above the aspen may be biased by approximately $10 \%$ upon removing data when wind is from this direction. Rather than trying to correct the data for these missing periods for the comparison of seasonal fluxes from the three sites (which may be problematic particularly for the $\mathrm{CO}_{2}$ flux data as the current version of the SHAW model does not simulate $\mathrm{CO}_{2}$ flux), we will note the discrepancy. However, extrapolation of the ET for the remainder of each month and for the missing months for use in the catchment water balance implicitly corrected for the bias, as described below.

In order to close the water balance, ET was extrapolated from the observed periods within each month and estimated for periods with missing data. For all months where measured fluxes were available during the 2007 water year, ET was extrapolated from the observed hours within each month to the entire month based on the ratio of simulated ET for the measured hours to that for the entire month. Adjusting observed ET by the ratio in simulated fluxes decreased annual estimated ET by $16 \mathrm{~mm}$ at the sagebrush site, $20 \mathrm{~mm}$ for the aspen understory and $38 \mathrm{~mm}$ for the above aspen compared to using simply the observed monthly averaged fluxes. Instrument malfunctions tend to occur during stormy weather, so it is consistent that the unadjusted flux values would overestimate annual ET.

For the aspen understory during September 2007 and for above aspen from October 2006 through January 2007 when measured latent heat fluxes were not available, ET was estimated based on the relation between measured and simulated ET for the remainder of the year. Fortunately these months are some of the lowest for ET, thereby minimizing the overall error introduced by the estimation. Estimated
ET totaled $61 \mathrm{~mm}$ for the four missing months above the aspen and $10 \mathrm{~mm}$ for the September understory; these represent $12 \%$ and $5 \%$ of the annual ET, respectively. By comparison, a simple regression with measured ET at the sagebrush would predict $13 \mathrm{~mm}$ less ET for the missing above aspen months and $5 \mathrm{~mm}$ more for the September understory, or about 3\% of the annual ET in both cases.

\subsection{Seasonal comparison of fluxes}

Average monthly energy and carbon fluxes for each site are plotted in Fig. 5e. Average net radiation was consistently higher above the aspen throughout the year compared to the other sites, due to its higher leaf area index and complex canopy. Albedo above the aspen ranged from 0.12 during the growing season to 0.45 during the snow-covered period, while that for the sagebrush was 0.17 to 0.77 . Average net radiation above the sagebrush was negative during months with snowcover and low sun angles (November through February) when albedo reached its highest. Tree trunks and limbs of the aspen contributed to the lower winter albedo and absorbed sufficient solar radiation to prevent negative net radiation for any month. Data were not available from the understory site for much of the snow-covered period, but the data did indicate negative net radiation in February and only slightly positive net radiation during November. More of the aspen trunks were buried by snow in February, resulting in the negative net radiation.

Figure 4 presents the average diurnal trace in the radiation fluxes for each month throughout the year. The dominant component in net radiation is the incoming solar radiation because the long-wave radiation measurements tend to cancel each other. The problems presented by the gaps in the canopy for measurement of the understory radiation is apparent in Fig. 4a, as incoming solar radiation for many of the mid-afternoon hours are very close to the above canopy measurements. Although incoming solar radiation is lower during the winter months, reflected radiation is actually higher due to the high albedo of the snow.

Incoming and emitted long-wave radiation fluxes plotted in Fig. 4 present some interesting contrasts between the three sites. As expected, downward long-wave radiation is nearly identical above the sagebrush and aspen, however the sheltering provided by the aspen canopy is evident from the much higher downward long-wave radiation for the aspen understory. Upward long-wave radiation is nearly identical for the sagebrush and aspen understory early in the year until the snowcover becomes discontinuous at the sagebrush site in March or April. During this period, solar radiation absorbed by the aspen caused upward long-wave radiation from the aspen to be slightly higher (approximately 2\%). Vegetation cover at the sagebrush site is sparse, allowing more soil to be exposed after snowmelt; this combined with the lower latent heat flux from the drier sagebrush site (Fig. 5b) caused upward long-wave fluxes from the sagebrush to be 

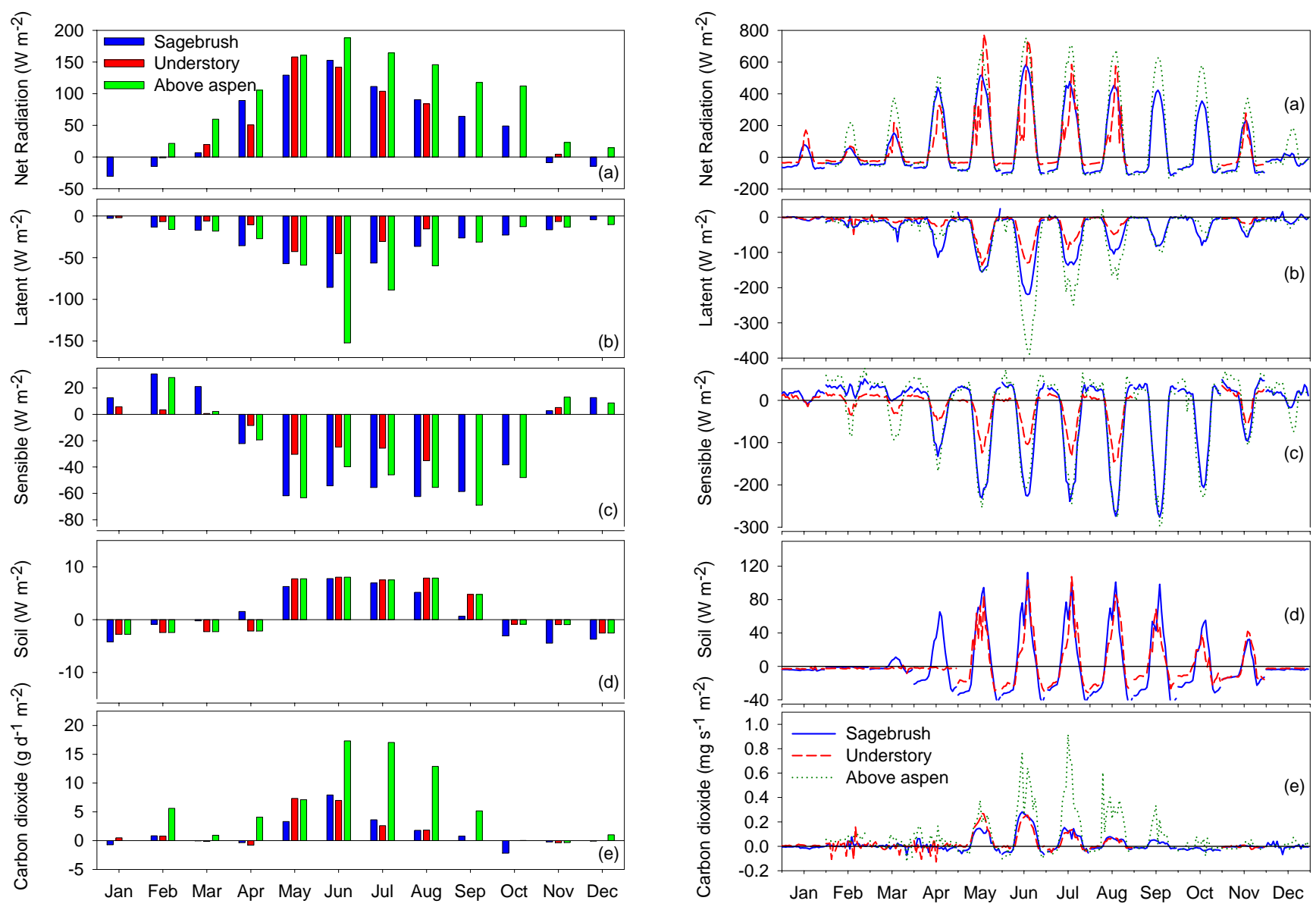

Fig. 5. Average surface energy and carbon fluxes measured for each month of the study period fluxes for the three study locations. (Data are not available for the aspen understory during September, October and December, nor for above the aspen during January; the two aspen sites share common soil heat flux sensors; the two aspen sites share common soil heat flux sensors.)

substantially higher than the other sites throughout the growing season (Fig. 4d). The evaporative cooling effect of the combined tree/grass system substantially lowers the surface temperature and upward long-wave radiation flux viewed by the above aspen net radiometer compared to the other sites. The reduced upward long-wave radiation persists through the growing season and even until December when snowcover resumes.

Figure 6 presents the average diurnal trace in the energy and carbon fluxes for each month throughout the year. As mentioned previously, net radiation measured in the understory is likely not representative of the understory; due to gaps in the canopy, direct radiation penetrated the canopy during the afternoon hours throughout the growing season (March through August), skewing the net radiation measurements. Morning measurements tended to be lower than the other two sites while afternoon measurements approached or exceeded net radiation above the canopy.

Fig. 6. Average diurnal variation in measured surface energy and carbon fluxes for the three study locations. (Data are not available for the aspen understory during September, October and December, nor for above the aspen during January; the two aspen sites share common soil heat flux sensors.)

Turbulent fluxes of sensible and latent heat are relatively small during the snow-covered period and tend to offset each other, so that the net turbulent flux $\left(H+L_{v} E\right)$ is quite small, as noted by other investigators (Garen and Marks, 2005; Link and Marks, 1999; Marks et al., 2002). ET and latent heat fluxes get an early start at the sagebrush site compared to the other locations as a result of early snowmelt and the perennial leaves on the sagebrush. By May, latent flux is very similar at all three sites, and the above aspen flux quickly surpasses the sagebrush site by June. The fact that latent heat fluxes for the aspen understory and above aspen sites are similar in May suggest that the aspen trees had not yet started to transpire, and the entire latent heat flux measured above the canopy originates from the understory. Latent heat flux clearly peaked in June at the sagebrush and above aspen canopies, while May and June fluxes are similar for the aspen understory (Figs. 5b and 6b). Leveling off of latent heat flux in June under the aspen canopy coincides with a drop 
in net radiation at this site (Fig. 5a); by June, leaf cover of the aspen shades the understory vegetation sufficiently to reduce evaporative demand. Latent heat flux above the aspen is consistently higher through the growing season, but is very nearly similar to the sagebrush site in September when the leaves fall from the aspen and much of the latent heat flux likely originates from the understory. Latent heat flux is actually higher from the sagebrush site during April and October compared to the other sites, due to the perennial leaf cover of the sagebrush.

Average daily sensible heat fluxes tend to be lower over the aspen compared to the sagebrush during the months when the aspen leaves are actively transpiring (Fig. 5); average daily fluxes ranged from 73 to $88 \%$ less than that over the sagebrush during the months from June to August. Interestingly, the diurnal trend in sensible heat flux above the aspen and sagebrush sites are quite similar during the non-snow period (April through November, Fig. 6c). This might be expected, given that the two sites are subject to nearly identical meteorological forces. Average daily fluxes were more negative above the aspen than the sagebrush during May, September and October. Absorption of solar radiation during these months was not offset by transpiration of the aspen, resulting in a higher proportion of the energy being dissipated by sensible heat flux. However the Bowen ratio, defined as the ratio of sensible to latent heat fluxes, are identical for the two sites during May (1.1) and September (2.2). Although the aspen had higher net radiation, the two sites partitioned the available energy between the turbulent fluxes similarly. In October, the Bowen ratio of the aspen rose further to 3.8 while that for the sagebrush dropped to 1.7 ; the decrease in October for the sagebrush was likely due to the sagebrush utilizing the precipitation that fell in September and October.

Bowen ratios suggest increased water stress as the growing season progressed. A typical value for well-watered vegetation is 0.2 (Campbell, 1977). Average daily Bowen ratios reached a minimum in June with values of $0.63,0.26$, and 0.55 for the sagebrush, aspen, and aspen understory, respectively. By August, soil moisture storage within the top $1 \mathrm{~m}$ had dropped to nearly its minimum; Bowen ratios rose to $1.71,0.93$, and 2.26, respectively, for August. The high Bowen ratio for the understory in August is in response to the soil profile drying down to at least $1 \mathrm{~m}$, causing the understory to senesce. The relatively low Bowen ratio above the aspen suggests that the aspen trees were able to access deeper water sources.

As expected, soil heat flux is small and slightly negative throughout the snow-covered period. Soil heat flux becomes positive and displays a diurnal trend when snowcover becomes discontinuous, which occurs in March at the sagebrush site and late April beneath the aspen. The sagebrush site, having more bare soil exposed, displays larger amplitude in the diurnal trace in soil heat flux. Net soil heat flux for both sites (the aspen sites shared a single set of soil heat flux instrumentation) becomes negative in October. In November, midday soil heat flux under the sagebrush falls below that for the aspen understory (Fig. 6d), which coincides with net radiation becoming negative at the sagebrush sites (Fig. 5a). The diurnal trace for carbon flux is rather noisy early in the year, but displays some interesting trends beginning in May. As with the latent heat flux, carbon flux from the aspen understory and above aspen sites are very similar in May, suggesting that nearly all of the latent heat and carbon flux originates below the aspen canopy. During this time, the aspen trees have not leafed out yet, but the grasses and forbs are flourishing. Carbon storage of the understory vegetation surpassed that of the sagebrush while the aspen understory vegetation was actively growing. Beginning in June, carbon flux to the sagebrush and aspen understory is very similar for the remainder of the growing season, even though ET is higher from the sagebrush canopy. Being more sheltered from the wind, the understory vegetation can use the available water more efficiently than the more exposed sagebrush site. Once the aspen begins to leaf out, carbon storage in the aspen canopy is substantial until the leaves drop. Net carbon flux becomes essentially zero during October and November for the aspen sites.

\subsection{Water budget for 2007 water year}

A water balance was computed to further demonstrate the quality of the flux measurements and their utility in closing the water balance. The catchment water balance for the 2007 water year (October 2006 through September 2007) is presented in Table 3 and seasonal timing of the water balance components are illustrated in Fig. 7. Typical of the Western US, the sites started the water year with a very dry soil profile, and soil storage increased with autumn precipitation. Soil moisture at the sagebrush site peaked in December and decreased during January due to the abnormally low precipitation. Soil moisture storage began a gradual decline beginning in March at the sagebrush site and at the end of April at the aspen site, which coincided with the end of snowmelt at the respective sites and the onset of active plant transpiration. Streamflow peaked in April and dropped rapidly as the soil profile began to dry. Based on areal coverage of the vegetation, an areal average ET of $425 \mathrm{~mm}$ was computed for the catchment. Latent heat flux from the sagebrush was very nearly the same as that above the aspen for most of the year (Fig. 5b), so the areal average ET mimics that from the sagebrush until June. Due in part to its larger coverage within the catchment, sagebrush accounts for approximately $63 \%$ of the total ET from the catchment, while the aspen trees account for $19 \%$ and the aspen understory accounts for $11 \%$. ET from the fir trees estimated from model simulation accounts for only $6 \%$ of the total catchment ET, so any error in its estimation has a very minor influence on the overall water balance. 
Table 3. Catchment water balance (in $\mathrm{mm}$ ) for water year 2007. (ET estimate for fir trees is based solely on model simulation.)

\begin{tabular}{llccc}
\hline & Site ET or precip & \% of area & Areal contribution & Catchment totals \\
& & & & \\
\hline Precipitation & & & & \\
Sagebrush & 690 & 69 & 476 & 699 \\
Aspen and Fir & 718 & 31 & 223 & \\
Total & & & & \\
Evapotranspiration & & 69 & 265 & \\
Sagebrush & 384 & 26 & 82 & \\
Aspen trees & 314 & 26 & 48 & 221 \\
Understory & 185 & 5 & 26 & 2 \\
Fir & 518 & & & 22 \\
Total & & & & \\
Steamflow & & & & \\
Soil water change & & & & \\
Error & &
\end{tabular}
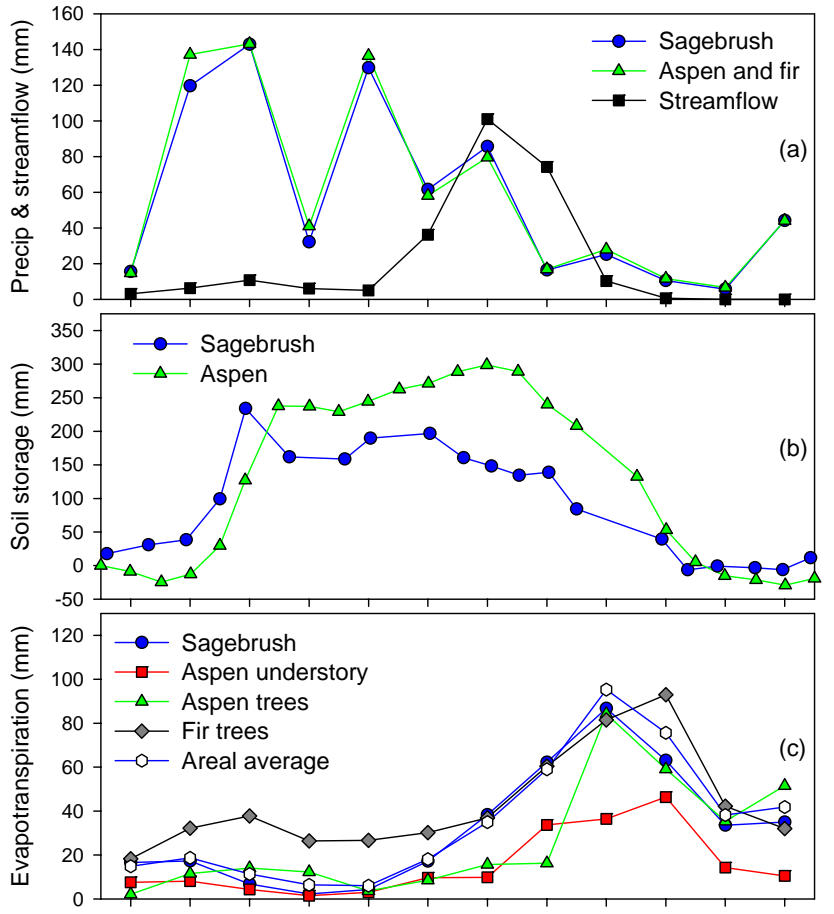

Oct Nov Dec Jan Feb Mar Apr May Jun Jul Aug Sep

Fig. 7. Monthly variation in water balance components, including precipitation, streamflow, change in soil water storage from the beginning of the water year, and evapotranspiration from each major plant type.

Precipitation measured at the sagebrush site was $690 \mathrm{~mm}$ for the 2007 water year and $718 \mathrm{~mm}$ at the aspen site. Total precipitation for the catchment was estimated based on a weighted average of precipitation measured within the respective vegetation zones by lumping the aspen and fir areas together, yielding an areal average precipitation of $699 \mathrm{~mm}$. Flerchinger and Cooley (2000) demonstrated that distributing precipitation based on vegetation coverage worked adequately for a catchment with similar variability in vegetation and precipitation within the Reynolds Creek Experimental Watershed.

Measured streamflow for the 2007 water year was $254 \mathrm{~mm}$. Water stored in the soil profile decreased by $19 \mathrm{~mm}$ at the aspen site, while that at the sagebrush site actually increased by $12 \mathrm{~mm}$ due to September precipitation. The net result is an estimated $2 \mathrm{~mm}$ increase in areal average soil water storage for the catchment, assuming water storage in the aspen and fir are similar. The simple water balance in Table 3 indicates an excess of $22 \mathrm{~mm}$ input into the basin than accounted for in the outflows; this translates to an error of about $3 \%$ of the annual precipitation. By comparison, Flerchinger and Cooley (2000) reported an average 10\% error in the water balance for a 10-year study of a separate intensively measured catchment within the Reynolds Creek Watershed. The tighter water balance closure in the present study may be attributed to direct measurement as opposed to simulation of the ET component and to a much greater percentage of the precipitation contributing to streamflow (36\% compared to $8 \%$ ). ET in the present study accounted for approximately $60 \%$ of the precipitation, which is much lower than the $88 \%$ reported by Flerchinger and Cooley (2000). However, cumulative ET from the sites is very comparable to that of Flerchinger and Cooley (2000), who reported an average of $376 \mathrm{~mm}$ from a low sagebrush site, and $504 \mathrm{~mm}$ from an aspen site.

The influence of the lack of energy balance closure for the EC measurements on the water balance was assessed. Turbulent fluxes during the snow-free months (May through October) at the sagebrush and above aspen sites were adjusted to force energy balance closure while maintaining the Bowen 
ratio (Twine et al., 2000). This was problematic when the Bowen ratio approached -1.0 ; therefore, whenever the magnitude of turbulent fluxes was greater than the error in the energy balance, the error was divided equally between the two components. Although, energy closure for the aspen understory was not attempted because the net radiation measurements were not representative, ET estimates at this site were not necessary to close the water balance. Forcing the turbulent fluxes to close the energy balance increased estimated ET above the aspen by $14 \mathrm{~mm}$, but decreased it by $15 \mathrm{~mm}$ for the sagebrush site. The opposite trend at the two sites is consistent with the slope and intercepts presented in Table 1; lack of closure would tend to overestimate the smaller turbulent fluxes and underestimate larger ones. The net effect of closing the energy balance decreased estimated ET by $6 \mathrm{~mm}$ but increased the water balance error from 22 to $28 \mathrm{~mm}$. Scott (2010) also found that closing the energy balance did not always improve water balance closure.

\section{Summary and conclusions}

Intermingling of sagebrush and aspen communities is a common feature throughout the forests and intermountain shrub steppe of the Western US (Barbour and Billings, 2000; Clark et al., 2001). The resulting mosaic of vegetation communities creates a challenge for measuring or modeling the energy and mass fluxes in these complex mountainous headwater catchments, as adequate fetch requirements and complex topography make interpretation of EC results difficult. EC measurements of fluxes of water and carbon over the dominant vegetation communities within this study provide information on the carbon and water flux dynamics of these very different vegetation types. This information allows us to use a model to extend these values over the spatial extent of these vegetation communities to close the catchment water balance.

A water balance of the catchment based on areal vegetation cover was closed to within $22 \mathrm{~mm}$, or about $3 \%$ of annual precipitation. Missing periods of measured data, due in part to screening for wind direction in this patchy vegetation, made it necessary to extrapolate measured fluxes to the missing periods. An approach using the ratio of simulated to measured ET fluxes was used to assess the representativeness of measured periods and to extrapolate to missing periods. Of the $699 \mathrm{~mm}$ of areal average precipitation, $421 \mathrm{~mm}$ was lost to ET, and $254 \mathrm{~mm}$ of streamflow was measured from the catchment. Forcing closure of the energy balance actually increased the error in the catchment water balance, which confirms reports of Scott (2010) that energy balance closure does not necessarily improve water balance closure. The tight closure of the catchment water balance demonstrates the quality of the measurements in this complex headwater catchment and justifies the approach used for extrapolating missing periods.
Total estimated ET was 384, 185, and $314 \mathrm{~mm}$ from the sagebrush, aspen understory and aspen trees, respectively, for the 2007 water year. The higher ET from the sagebrush can be attributed to its perennial leaves and the general windexposed nature of the site. Though ET from the aspen community was higher $(499 \mathrm{~mm})$ than that for the sagebrush, because the sagebrush community occupies nearly $70 \%$ of the catchment area, it accounts for about $63 \%$ of total catchment ET. The sagebrush community clearly dominates water usage within the catchment.

Bowen ratio and soil moisture observations suggest a decoupling of the moisture source for the understory and aspen trees by mid-summer. The aspen trees apparently had access to a deeper water source than the roots of the understory. Scott et al. (2003) and Paco et al. (2009) found similar results in the apparent decoupling of the moisture source for the understory versus the overstory of open woodland canopies due also to the trees tapping deeper moisture.

This study highlights the influence of these vegetation communities on surface energy and carbon fluxes across these landscapes. Differences in the surface energy and carbon fluxes between a sagebrush site, aspen canopy, and aspen understory were modulated by the characteristics of the three vegetation types. Perennial leaves of the sagebrush enabled higher rates of ET and latent heat flux during the early and late portions of the growing season compared to the aspen sites. Conversely, the aspen understory experienced the highest net radiation, carbon, ET, and latent heat fluxes in May, prior to the aspen trees leafing out. Latent heat and carbon flux at the aspen site during this period originated almost entirely from the understory. The presence of the aspen also modulated the partitioning of the turbulent fluxes at the site; sensible heat flux from the aspen tended to be slightly less than the sagebrush site during the growing season when the leaves were actively transpiring, but exceeded that from the sagebrush in May, September and October when net radiation was not offset by evaporative cooling of the aspen leaves. Carbon flux to the sagebrush and aspen understory was very similar for much of the growing season, even though ET was higher from the sagebrush canopy. Being more sheltered from the wind, the understory vegetation used the available water more efficiently than the more wind-exposed. Carbon flux to the aspen trees far surpassed that used by either the aspen understory or sagebrush. Results from this study demonstrate the utility of EC systems in providing information required to close the water balance of headwater catchments. It also illustrates the influence of vegetation on the spatial complexity and variability of surface fluxes across mountainous headwater landscapes.

Edited by: W. Quinton 


\section{References}

Arain, M. A., Black, T. A., Barr, A. G., Griffis, T. J., Morgenstern, K., and Nesic, Z.: Year-round observations of the energy and water vapour fluxes above a boreal black spruce forest, Hydrol. Process., 17, 3581-3600, 2003.

Baldocchi, D., Finnigan, J., Wilson, K., Paw U, K. T., and Falge, E.: On measuring net ecosystem carbon exchange over tall vegetation on complex terrain, Bound.-Lay. Meteorol., 96, 257-291, 2000a.

Baldocchi, D. D., Law, B. E., and Anthoni, P.: On measuring and modeling energy fluxes above the floor of a homogeneous and heterogeneous conifer forest, Agr. Forest Meteorol., 102(2-3), 187-206, 2000b.

Baldocchi, D. D., Xu, L., and Kiang, N.: How plant functionaltype, weather, seasonal drought, and soil physical properties alter water and energy fluxes of an oak-grass savanna and an annual grassland, Agr. Forest Meteorol., 123, 13-29, 2004.

Barbour, M. G. and Billings, W. D.: North American Terrestrial Vegetation, 2nd edn., Cambridge University Press, Cambridge Massachusetts, 616 p., 2000.

Blanken P. D., Black, T. A., Yang, P. C., den Hartog, G., Neumann, H. H., Nesic, Z., Novak, M. D., Staebler, R., Lee, X.: Energy balance and surface conductance of a boreal aspen forest: partitioning overstory and understory components, J. Geophys. Res., 102, 28915-28927, 1997.

Blanken, P. D., Black, T. A., Neumann, H. H., den Hartog, G., Yang, P. C., Nesic, Z., and Lee, X.: The seasonal water and energy exchange above and within a boreal aspen forest, J. Hydrol., 245, 118-136, 2001.

Campbell, G. S.: An Introduction to Environmental Biophysics, Springer-Verlag, New York, p. 136, 1977.

Clark, P. E., Seyfried, M. S., and Harris, B.: Intermountain plant community classification using Landsat TM and SPOT HRV Data, J. Range Manage., 54, 152-160, 2001.

Constantin, J., Grelleb, A., Ibroma, A., and Morgensterna, K.: Flux partitioning between understorey and overstorey in a boreal spruce/pine forest determined by the eddy covariance method, Agr. Forest Meteorol., 98-099, 629-643, 1999.

Flerchinger, G. N. and Cooley, K. R.: A ten-year water balance of a mountainous semi-arid watershed, J. Hydrol., 237(1-2), 86-99, 2000.

Flerchinger, G. N., Hanson, C. L., and Wight, J. R.: Modeling evapotranspiration and surface energy budgets across a watershed, Water Resour. Res., 32(8), 2539-2548, 1996.

Flerchinger, G. N., Cooley, K. R., Hanson, C. L., and Seyfried, M. S.: A uniform versus an aggregated water balance of a semi-arid watershed, Hydrol. Process., 12, 331-342, 1998.

Fox, J.: Applied Regression Analysis and Generalized Linear Models, Sage Publications, Los Angeles, California, 665 pp., 2008.

Garen, D. C. and Marks, D.: Spatially distributed energy balance snowmelt modelling in a mountainous river basin: estimation of meteorological inputs and verification of model results, J. Hydrol., 315, 126-153, 2005.

Hanson, C.: Long-term precipitation database, Reynolds Creek experimental watershed, Idaho, USA, Water Resour. Res., 37(11), 2831-2834, 2001.

Hanson, C. L.: Precipitation catch measured by the Wyoming shield and the dual-gauge systems, Water Resour. Bull., 25, 159-164, 1989.
Hanson, C. L., Johnson, G. L., and Rango, A.: Comparison of precipitation catch between nine measuring systems, J. Hydrol. Eng., 4, 70-75, 1999.

Hanson, C. L., Pierson, F. B., and Johnson, G. L.: Dual-gauge system for measuring precipitation: historical development and use, J. Hydrol. Eng., 9(5), 350-359, 2004.

Hiller, R., Zeeman, M. J., and Eugster, W.: Eddy-covariance flux measurements in the complex terrain of an alpine valley in Switzerland, Bound.-Lay. Meteorol., 127, 449-467, 2008.

Jarosz, N., Brunet, Y., Lamaud, E., Irvine, M., Bonnefond, J., and Loustau, D.: Carbon dioxide and energy flux partitioning between the understorey and the overstorey of a maritime pine forest during a year with reduced soil water availability, Agr. Forest Meteorol., 148, 1508-1523, 2008.

Johnson, G. L. and Hanson, C. L.: Topographic and atmospheric influences on precipitation variability over a mountainous watershed, J. Appl. Meteorol., 34, 68-87, 1995.

Kaimal, J. C. and Finnigan, J. J.: Atmospheric Boundary Layer Flows - Their Structure and Measurement, Oxford University Press, New York, NY, 289 pp., 1994.

Kosugi, Y., Takanashi, S., Tanaka, H., Ohkubo, S., Tani, M., Yano, M., and Katayama, T.: Evapotranspiration over a Japanese cypress forest. I. Eddy covariance fluxes and surface conductance characteristics for 3 years, J. Hydrol., 337, 269-283, 2007.

Lamaud, E., Ogée, J., Brunet, Y., and Berbigier, P.: Validation of eddy flux measurements above the understorey of a pine forest, Agr. Forest Meteorol., 106, 187-203, 2001.

Link, T. E. and Marks, D.: Distributed simulation of snowcover mass-and energy-balance in the boreal forest, Hydrol. Process., 13, 2439-2452, 1999.

Link, T. E., Flerchinger, G. N., Unsworth, M. H., and Marks, D.: Simulation of water and energy fluxes in an old growth seasonal temperate rainforest using the Simultaneous Heat and Water (SHAW) Model, J. Hydrometeorol., 5(3), 443-457, 2004.

Marks, D. and Winstral, A.: Comparison of snow deposition, the snowcover energy balance, and snowmelt at two sites in a semiarid mountain basin, J. Hydrometeorol., 2(3), 213-227, 2001.

Marks, D., Winstral, A., and Seyfried, M.: Simulation of terrain and forest shelter effects on patterns of snow deposition, snowmelt and runoff over a semi-arid mountain catchment, Hydrol. Process., 16, 3605-3626, 2002.

Marks, D., Reba, M., Pomeroy, J., Link, T., Winstral, A., Flerchinger, G., and Elder, K.: Comparing simulated and measured sensible and latent heat fluxes over snow under a pine canopy, J. Hydrometeorol., 9(6), 1506-1522, 2008.

Misson, L., Baldocchi, D. D., Black, T. A., Blanken, P. D., Brunet, Y., Curiel Yuste, J., Dorsey, J. R., Falk, M., Granier, A., Irvine, M. R., Jarosz, N., Lamaud, E., Launiainen, S., Law, B. E., Longdoz, B., Loustau, D., McKay, M., Paw U, K. T., Vesala, T., Vickers, D., Wilson, K. B., and Goldstein, A. H.: Partitioning forest carbon fluxes with overstory and understory eddy-covariance measurements: a synthesis based on FLUXNET data, Agr. Forest Meteorol., 144, 14-31, 2007.

Molotch, N. P., Blanken, P. D., Williams, M. W., Turnipseed, A. A., Monson, R. K., and Margulis, S. A.: Estimating sublimation of intercepted and sub-canopy snow using eddy covariance systems, Hydrol. Process., 21, 1567-1575, 2007.

Paco, T. A., David, T. S., Henriques, M. O., Pereira, J. S., Valente, F., Banza, J., Pereira, F. L., Pinto, C., and David, J. S.: 
Evapotranspiration from a Mediterranean evergreen oak savannah: the role of trees and pasture, J. Hydrol., 369, 98-106, 2009.

Pierson, F. B., Slaughter, C. W., Cram, Z. K.: Long-term discharge and suspended-sediment database, Reynolds Creek experimental watershed, Idaho, USA, Water Resour. Res., 37(11), 2857-2861, 2001.

Pomeroy, J., Toth, B., Granger, R., Hedstrom, N., and Essery, R.: Variation in surface energetics during snowmelt in complex terrain, J. Hydrometeorol., 4(4), 702-716, 2003.

Roupsard, O., Bonnefond, J., Irvine, M., Berbigier, P., Nouvellon, Y., Dauzat, J., Taga, S., Hamel, O., Jourdan, C., SaintAndré, L., Mialet-Serra, I., Labouisse, J., Epron, D., Joffre, R., Braconnier, S., Rouzière, A., Navarro, M., and Bouillet, J.: Partitioning energy and evapo-transpiration above and below a tropical palm canopy, Agr. Forest Meteorol., 139, 252-268, 2006.

Reba, M., Marks, D., Link, T., and Pomeroy, J.: Inter-annual comparison of measured turbulent fluxes over snow at a windsheltered and wind-exposed site using eddy covariance, in: Hydrology in Mountain Regions: Observations, Processes and Dynamics, Wallingford, UK, IAHS Publication 326, 34-40, 2009a.

Reba, M. L., Marks, D., Pomeroy, J., and Link, T. E.: An assessment of corrections to turbulent fluxes over snow by eddy covariance in mountain environments, Water Resour. Res., 45, W00D38, doi:10.1029/2008WR007045, 2009b.

Schmid, H. P.: Footprint modeling for vegetation atmosphere exchange studies: a review and perspective, Agr. Forest Meteorol., 113, 159-183, 2002.

Schuepp, P. H., Leclerc, M. Y., MacPerson, J. I., and Desjardins, R. L.: Footprint prediction of scalar fluxes from analytical solutions of the diffusion equation, Bound.-Lay. Meteorol., 50, 355-373, 1990.

Schotanus, P., Nieuwstadt, F. T. M., and De Bruin, H. A. R.: Temperature measurement with sonic anemometer and its application to heat and moisture fluxes, Bound.-Lay. Meteorol., 26, 81-93, 1983.

Scott R. L.: Using watershed water balance to evaluate the accuracy of eddy covariance evaporation measurements for three semiarid ecosystems, Agr. Forest Meteorol., 150, 219-225, 2010.

Scott, R. L., Watts, C., Payan, J. G., Edwards, E., Goodrich, D. C., Williams, D., and Shuttleworth, W. J.: The understory and overstory partitioning of energy and water fluxes in an open canopy, semiarid woodland, Agr. Forest Meteorol., 114, 127-138, 2003.
Twine, T. E., Kustas, W. P., Norman, J. M., Cook, D. R., Houser, P. R., Meyers, T. P., Prueger, J. H., Starks, P. J., and Wesely, M. L.: Correcting eddy-covariance flux underestimates over a grassland, Agr. Forest Meteorol., 103, 279-300, 2000.

Turnipseed, A. A., Blanken, P. D., Anderson, D. E., and Monson, R. K.: Energy budget above a high-elevation subalpine forest in complex topography, Agr. Forest Meteorol., 110, 177-201, 2002.

Turnipseed, A. A., Anderson, D. E., Blanken, P. D., Baugh, W. M., and Monson, R. K.: Airflows and turbulent flux measurements in mountainous terrain part 1. Canopy and local effects, Agr. Forest Meteorol., 119, 1-21, 2003.

Webb, E. K., Pearman, G. I., and Leuning, R.: Correction of flux measurements for density effects due to heat and water vapor transfer, Q. J. Roy. Meteor. Soc., 106, 85-100, 1980.

Wilson K. B. and Baldocchi, D. D.: Seasonal and interannual variability of energy fluxes over a broadleaved temperate deciduous forest in North America, Agr. Forest Meteorol., 100, 1-18, 2000.

Wilson K. B. and Meyers, T. P.: The spatial variability of energy and carbon dioxide fluxes at the floor of a deciduous forest, Bound.Lay. Meteorol., 98, 443-473, 2001.

Wilson K. B., Hanson, P. J., and Baldocchi, D. D.: Factors controlling evaporation and energy partitioning beneath a deciduous forest over an annual cycle. Agr. Forest Meteorol. 102, 83-103, 2000.

Wilson, K., Goldstein, A., Falge, E., Aubinet, M., Baldocchi, D., Berbigier, P., Bernhofer, C., Ceulemans, R., Dolmanh, H., Field, C., Grelle, A., Ibrom, A., Lawl, B. E., Kowalski, A., Meyers, T., Moncrieff, J., Monson, R., Oechel, W., Tenhunen, J., Valentini, R., and Verma, S.: Energy balance closure at FLUXNET sites, Agr. Forest Meteorol., 113, 223-243, 2002.

Winstral, A. and Marks, D.: Simulating wind fields and snow redistribution using terrain-based parameters to model snow accumulation and melt over a semi-arid mountain catchment, Hydrol. Process., 16(18), 3585-3603, 2002.

Wu, J., Guan, D., Han, S., Shi, T., Jin, C., Pei, T., and Yu, G.: Energy budget above a temperate mixed forest in Northeastern China, Hydrol. Process., 21, 2425-2434, 2007. 